\title{
ESQ DALAM KEPEMIMPINAN PENDIDIKAN
}

\author{
ALI RIDHO \\ (STAI Al-Khairat Pamekasan) \\ Email: Aldo.okfor@gmail.com
}

\begin{abstract}
Education which is a system in the perspective of anthology is an attempt to humanize humans by an appropriate manner to achieve very high humane values as an attempt to change as well as to move the cultural values to any individual in society. But this view is difficult to achieve when the belief that a person's success will occur due to the efforts started early in order to organize their future without having an education. This paper will provide a breakthrough through leadership of education that is not only based on good intellectual ability, but also good emotional and spiritual. With the result that it will contribute qualified modern human resources. Modern human Resources is a human being who has the potential of ad equated intellectual quality. However, sometimes the potential is empty because it is not matched by the quality of the good faith or emotional. In the fact, they (modern humans) have good reasoning capability. However, the success which is useful in the future whether for themselves, the community, the nation and the state are not only enough by having logical thought only. But, it also requires EQ Emotional Quotient (level of emotional or personality), CQ Creativity Quotient (level of creativity) and SQ Spiritual Quotient (level religiosities or faith and devotion to God. Thus, the national education system must be able to provide a solution- which is able to break of the empty circle of values and morals happening in education system around us. the empty circle we must combine as well as put the intellectual intelligence, emotional intelligence, and spiritual intelligence known as ESQ in order to get balance between the fulfillment of rights and vertical or horizontal obligations. ESQ is a role of the leadership of its resources which include Human Resources and Natural Resources with the organization as a model of leadership in education. ESQ if applied in educational leadership level, it would be beneficial along with the growth and development of the educational organization with the growth of moral values.
\end{abstract}

\begin{abstract}
Abstrak
Pendidikan merupakan sebuah sistem dalam perspektif ontologik adalah suatu upaya memanusiakan manusia dengan cara yang manusiawi demi tercapainya nilai kemanusiaan yang sangat tinggi sebagai suatu upaya merubah dan memindahkan nilai kebudayaan kepada setiap individu dalam masyarakat. Namun di lapangan konstruksi ini sulit terwujud ketika keyakinan bahwa kesuksesan seseorang akan terjadi karena adanya upaya menata mulai dini demi masa depannya tanpa harus
\end{abstract}


menerima pendidikan. Tulisan ini akan memberikan terobosan melalui sebuah kepemimpinan pendidikan yang bukan hanya berlandaskan pada kemampuan intelektual yang baik, namun kemampuan emosional dan dan spritual yang baik pula, sehingga tercipta sebuah Sumber Daya Manusia modern yang berkualitas. Sumber Daya Manusia modern adalah manusia yang mempunyai potensi kualitas intelektual yang memadai. Namun, terkadang potensi tersebut menjadi kosong karena tidak diimbangi oleh kualitas iman atau emosional yang baik. Secara the facto mareka (manusia modern) mempunyai kemampuan pemikiran yang bagus. Namun, kesuksesan yang bermanfaat di masa yang akan datang baik bagi dirinya, masyarakat, bangsa dan negara tidak hanya cukup ditempuh kemampuan pemikiran saja. memerlukan EQ Emotional Quotient (tingkat emosional atau kepribadian), CQ Creativity Quotient (tingkat kreativitas) dan SQ Spritual Quotient (tingkat relegiusitas atau keimanan dan ketakwaan terhadap Tuhan). Dengan demikian, sistem pendidikan nasional harus mampu memberikan tawaran solutif yang mampu keluar dari lingkaran kosong tanpa adanya nilai dan moral yang selama ini terjadi di pendidikan sekitar kita. Lingkaran yang kosong itu harus kita sinerginakan antara kecerdasan intlektual, kecerdasan emosi, dan kecerdasan spritual atau lebih dikenal dengan ESQ demi menatap kehidupan yang serara dan seimbang antara pemenuhan hak dan kewajiban vertikal maupun horizontal. ESQ merupakan wilayah kepemimpinan terhadap Sumber Daya yang dimilikinya yang meliputi Sumber Daya Manusia (SDM) maupun Sumber Daya Alam (SDA) dengan model kepemimpinan organisasi sebagaimana dalam pendidikan. apabila ESQ diaplikasikan dalam tataran kepemimpinan kependidikan, akan bermanfaat seiring dengan pertumbuhan dan perkembangan organisasi kependidikan dengan pertumbuhan nilai moral.

Kata kuci: Pendidikan, ESQ, Kepemimpinan

\section{Pendahuluan}

Kepemimpinan adalah kemampuan dan kesiapan yang dimiliki seseorang untuk mempengaruhi, mendorong, mengajak, menuntun, menggerakkan orang lain untuk melakukan sesuatu demi tercapainya tujuan tertentu1. Pendapat ini sama dengan Robbinsn sebagaimana dikutip oleh Zamroni dan Umiarso, kepemimpinan adalah kemampuan mempengaruhi kelompok ke arah pencapaian tujuan $^{2}$. Owens mendefinisikan kepemimpinan sebagai suatu interaksi antara satu

\footnotetext{
${ }^{1}$ Zamroni, MA. \& Umiarso, ESQ \& Model Kepemimpinan, (Semarang: raSAIL Media Group, 2011), 8.

2 Sudarwan Danim dan Suparno, Managemen dan Kepemimpinan Transformasional Kekepala Sekolahan, (Jakarta: Renika Cipta, 2009), 41.
} 
pihak sebagai yang memimpin dengan pihak yang dipimpin ${ }^{3}$. Sedangkan James Lipham, mendefinisikan kepemimpinan adalah permulaan dari suatu struktur atau prosedur baru untuk mencapai tujuan-tujuan dan sasaran organisasi atau untuk mengubah tujuan-tujuan dan sasaran organisasi. Serta banyak lagi definisidefinisi yang dilontarkan oleh tokoh-tokoh pendidikan baik lokal maupun dunia.

Dari beberapa definisi kepemimpinan tersebut diatas disimpulkan bahwa kepemimpinan adalah upaya mempengaruhi orang lain agar bekerjasama dalam upaya mencapai tujuan yang telah ditetapkan. Dari definisi tersebut juga dapat ditarik adanya unsur-unsur yang harus terdapat dalam kepemimpinan, yaitu ;

a. Orang yang mempengaruhi orang lain dalam satu pihak

b. Orang yang dapat dipengaruhi di pihak yang lain

c. Adanya maksud-maksud atau tujuan-tujuan tertentu yang hendak dicapai

d. Adanya serangkaian tindakan tertentu untuk mempengaruhi dan untuk mencapai maksud atau tujuan tertentu tersebut

e. Adanya kemanfaatan yang harus diperoleh bersama.

Apabila pengertian kepemimpinan ini dipadukan dengan istilah pendidikan maka akan menjadi kepemimpinan pendidikan. Pendidikan sendiri menurut Langeveld sebagaimana dikutip oleh Hendayat Soetopo dan Waty Soemanto, adalah membimbing anak didik dari tingkat belum dewasa menuju kedewasaan. Ki Hajar Dewantara (Bapak Taman Siswa) menganggap pendidikan sebagai daya upaya untuk mewujudkan bertumbuhnya budi pekerti (kekuatan batin, karakter, pikiran) dan tubuh anak untuk memajukan kehidupan anak didik selaras dengan dunianya ${ }^{5}$.

Ketika dua definisi ini dipadukan Dirawat mendefinisikan sebagaimana dikutip oleh Hendayat Soetopo dan Waty Soemanto "satu kemampuan dan proses mempengaruhi, membimbing, mengkoordinir dan menggerakkan orangorang lain yang ada hubungan dengan pengembangan ilmu pendidikan dan pelaksanaan pendidikan dan pengajaran, agar supaya kegiatan-kegiatan yang dijalankan dapat lebih efisien dan efektif di dalam pencapaian tujuan-tujuan pendidikan dan pengajaran' 6 .

Lebih singkatnya, kepemimpinan pendidikan merupakan kemampuan untuk menggerakkan pelaksanaan pendidikan untuk mencapai tujuan pendidikan. Dan penulis kira pengertian ini senada dengan filosofi kepemimpinan yang pada dasarnya menjunjung tinggi hubungan kemanusiaan.

\section{Pendekatan Studi Kepemimpinan}

${ }^{3}$ Zamroni, MA. \& Umiarso, ESQ E Model Kepemimpinan, (Semarang: raSAIL Media Group, 2011), 8.

4 Drs. Hendayat Soetopo, Drs. Waty Soemanto, Kepemimpinan dan Supervisi, (Malang: PT. Bina Aksara, 1984), 4.

${ }^{5}$ Drs. Hendayat Soetopo, Drs. Waty Soemanto, Kepemimpinan dan Supervisi, (Malang: PT. Bina Aksara, 1984), 4.

6 Dr. H. Fatah Syukur NC, M.Ag., Managemen Pendidikan Berbasis Pada Madarasah, (Semarang: PT. Pustaka Rizki Putra, 2002), 27. 
Di dalam memahami tentang kepemimpinan, banyak orang telah melakukan penelitian terkait hal tersebut. Penelitian-penelitian tersebut telah melahirkan teori-teori baru tentang kepemimpinan. Teori-teori inilah yang selanjutnya akan dipergunakan sebagai bahan studi bagi orang lain dan demikianlah seterusnya, berputar bagaikan sebuah roda yang menggelinding terus pada sumbunya. Fatah Syukur dalam kaitannya dengan teori kepemimpinan mengupas adanya pendekatan sifat atau yang diistilahkan dengan teori sifat, yang mana didalamnya sendiri terdapat dua hal yaitu postif dan negatif. Sifat positif sebagaimana dia kutip dari Davis (1983) meliputi dewasa, leluasa, cerdas, humoris, prestatif. Sedangkan sifat negatif seperti yang dia kutip dari Stogdill (1974) seperti kaku, apatis, sarkatis, otoriter, serta uniformed ${ }^{7}$.

Selanjutnya Fatah Syukur melanjutkan kaitannya dengan teori kepemimpinan dengan tiga pendekatan8, yaitu;

a. Pendekatan Sifat-Sifat Kepemimpinan

Pendekatan ini menekankan pada kualitas pemimpin. Keberhasilan pemimpin ditandai oleh daya kecakapan luar biasa yang dimiliki oleh pemimpin seperti;

1) Tidak kenal lelah atau penuh energi

2) Instuisi yang tajam

3) Tinjauan ke masa depan yang tidak sempit

4) Kecakapan meyakinkan yang sangat menarik

Menurut Wahjosumidjo ada tiga macam sifat pribadi seorang pemimpin, yang meliputi :

1) Ciri-ciri fisik (physical characteristics)

Seperti : tinggi badan, penampilan, energi.

2) Kepribadian (personality)

Seperti menjunjung tinggi harga diri, berpengaruh dan stabilitas emosi.

3) Kemampuan/kecakapan (ability)

Seperti kecerdasan umum, lancar berbicara, keaslian (original) dan wawasan sosial9.

Sifat-sifat pribadi ini sangat berperan terhadap keberhasilan seorang pemimpin baik di perusahaan, pemerintahan maupun di lembaga pendidikan.

b. Pendekatan Perilaku

Pendekatan perilaku memandang bahwa kepemimpinan dapat dipelajari dari pola tingkah laku dan bukan dari sifat-sifat (traits) pemimpin.

Alasannya sifat seseorang relatif sukar untuk diidentifikasikan, bebeapa pandangan ahli dia kutip antara lain James Owen (1973) berkeyakinan

7 Dr. H. Fatah Syukur NC, M.Ag., Managemen Pendidikan Berbasis Pada Madarasah, (Semarang: PT. Pustaka Rizki Putra, 2002), 28.

8 Wahyosumidjo, Kepemimpinan Kepala Sekolah, (Jakarta: PT RajaGrafido Persada, 2010), 2122.

9 Dr. H. Fatah Syukur NC, M.Ag., Managemen Pendidikan Berbasis Pada Madarasah, (Semarang: PT. Pustaka Rizki Putra, 2002), 28. 
bahwa perilaku dapat dipelajari, hal ini berarti bahwa orang yang dilatih dalam perilaku kepemimpinan yang tepat akan dapat memimpin secara efektif ${ }^{10}$.

Pendekatan ini menekankan pentingnya perilaku yang dapat diamati atau yang dilakukan oleh para pemimpin dari sifat-sifat pribadi atau sumber kewibawaan yang dimilikinya

c. Pendekatan Situasional

Pendekatan situasional berpandangan bahwa keefektifan kepemimpinan bergantung pada kecocokan antar pribadi, tugas, kekuasaan, sikap dan persepsi.

Selain tiga tersebut, Wahjosumidjo menambahkan dengan pendekatan menurut pengaruh kewibawaan. Yang mana menurut pandangan ini keberhasilan pemimpin dipandang dari segi sumber dan terjadinya sejumlah kewibawaan yang ada pada para pemimpin, dan dengan cara yang bagaimana para pemimpin menggunakan kewibawaan tersebut kepada bawahan ${ }^{11}$.

\section{Tipe Kepemimpinan}

Sebuah organisasi sangat membutuhkan adanya pimpinan yang berfungsi mengarahkan unit-unit atau kelompok dalam mencapai tujuan yang diinginkan. Menurut John R. Schermerrhorrn, JR., sebagaimana dikutip oleh Zainuddin Syarif, Leadership is the process of inspiring others to work hard to accoplish important tasks. Artinya seorang pemimpin berusaha memberikan semangat kepada yang lainnya untuk bekerja keras dalam menyelesaikan tugas penting. Sebab maju mundurnya organisasi dalam hal ini lembaga pendidikan sangatlah bergantung terhadap gaya ataupun tipe yang dimiliki oleh pemimpin ${ }^{12}$.

Bentuk-bentuk kepemimpinan sering kita jumpai dalam kehidupan masyarakat sehari-hari. Tetapi selain itu di sekolahpun terdapat berbagai macam tipe kepemimpinan ini. Sesuai dengan situasi saat ini dimana kita berada di tengah-tengah perjuangan menuju kesuksesan. Tujuan pendidikan tidak lepas dan sangat membutuhkan tipe-tipe pemimpin, sebagai pemimpin pendidikan yang officiat leader, yang cara kerja dan cara bergaulnya dapat dipertanggungjawabkan dan bisa menggerakkan orang lain untuk turut andil dalam menjalakan kehidupan yang bermanfaat bagi sesama. Menurut Hendayat Soetopo dan Waty Soemanto ada 4 tipe kepemimpinan ${ }^{13}$ yang terdiri dari :

${ }_{10}$ Wahyosumidjo, Kepemimpinan Kepala Sekolah, (Jakarta: PT RajaGrafido Persada, 2010), 20

11 Dr. Zainuddin Syarif, M.Ag, Dinamisasi Manajemen Pesantren ; dari tradisional hingga modern, (Yogyakarta: Sunan Kalijaga Press, 2007), 87.

12 Drs. Hendayat Soetopo, Drs. Waty Soemanto, Kepemimpinan dan Supervisi, (Malang: PT. Bina Aksara, 1984), 6.

13 Zamroni, MA. \& Umiarso, ESQ \& Model Kepemimpinan, (Semarang: raSAIL Media Group, 2011), 95. 
a. Tipe Autoritarian

Dalam tipe kepemimpinan semacam ini, pemimpin lebih bersifat berkuasa, suasana di sekolah selalu tegang. Pemimpin sama sekali tidak memberi kebebasan kepada anggotaa kelompok untuk turut ambil bagian dalam memutuskan suatu persoalan. Di sini pemimpin mendikte anggota yang ada di bawah kepemimpinannya tentang apa yang harus dikerjakan dan bagaimana harus mengerjakannya.

Inisiatif dan daya pikir anggota sangat dibatasi, sehingga tidak diberi kesempatan untuk mengeluarkan pendapat mereka. Kepala sekolah bebas membuat suatu peraturan sendiri dan peraturan-peratuan tersebut harus diikuti dan ditaati oleh anggota, akhirnya tindakan yang seperti inilah yang tidak bisa menciptakan kegembiraan kerja dari suatu kelompok, sebab bawahan merasa di permainkan dan tidak adanya harga diri.

b. Tipe Laizzes-faire (kebebasan)

Sifat kepemimpinan pada tipe ini seakan-akan \tidak nampak, sebab pada tipe ini seorang pemimpin memberikan kebebasan penuh kepada para anggotanya dalam melaksanakan tugasnya, atau secara tidak langsung segala peraturan, kebijaksanaan suatu institusi berada di tangan anggota.

Anggota kelompok bekerja menurut kehendaknya masing-masing tanpa adanya pedoman kerja yang baik. Disini seorang pemimpin mempunyai keyakinan bahwa dengan memberikan kebebasan yang seluas-luasnya terhadap bawahan, maka semua usahanya akan cepat berasil.

Apabila hal ini kita jumpai di sekolah, maka dalam hal ini bila akan menyelenggarakan rapat guru biasa dilaksanakan tanpa kontak pimpinan, tetapi bisa dilaksanakan tanpa acata. Rapat bisa dilaksanakan selagi anggota/guru-guru dalam sekolah tersebut menghendakinya.

c. Tipe Demokratis

Pemimpin yang demokratis menganggap dirinya sebagai bagian dari kelompoknya dan bersama-sama dengan kelompoknya berusaha bertanggung jawab tentang terlaksananya tujuan bersama ${ }^{14}$.

Selama ini kepemimpinan yang selalu kita harapkan adalah bentuk kepemimpinan yang demokratis. Yang mana dalam kepemimpinan ini seorang pemimpin selalu mengikut sertakan seluruh anggota kelompoknya dalam mengambil keputusan, kepala sekolah yang bersifat demikian akan selalu menghargai pendapat atau kreasi anggotanya/guru-guru yang ada dibawahnya dalam rangka membina sekolahnya. Kepala sekolah memberikan sebagian kepemimpinannya/kekuasaannya kepada bawahan, sehingga para bawahan, sehingga para bawahan merasa turut bertanggung jawab terhadap pelaksanaan program pendidikan dan pengajaran di sekolah.

${ }^{14}$ Annaurrahman, Belajar dan Pembelajaran, (Bandung: Alfabeta, 2009), 4 
Kepala sekolah sebagai seorang pemimpin lebih mementingkan kepentingan bersama dari pada kepentingan sendiri, sehingga terciptalah hubungan dan kerja sama yang baik dan harmonis, saling bantumembantu di dalam melaksanakan tugas sehari-hari sudah barang tentu dengan terciptanya suasana kerja yang sehat ini baik guru, tat usaha dan kepala sekolah bekerja dengan kegembiraan den kesenangan hati untuk memajukan rencana pendidikan di sekolah.

d. Tipe Pseudo Demokratis

Tipe kepemimpinan yang dimaksudkan adalah Demokrasi yang semu: artinya seorang pemimpin yang mempunyai sifat pseudo demokratis hanya menampakkan sikapnya saja yang demokratis, di balik kata-katanya yang penuh tanggung jawab ada siasat yang sebenarnya merupakan tindakan yang absolut. Pimpinan yang pseudo demokratis penuh dengan manipulasi sehingga pendapatnya sendiri yang harus disetujui.

\section{Faktor yang Mempengaruhi Efektivitas Pemimpin dalam Pendidikan}

Pemimpin yang mampu menumbuhkan suasana dialogis, kesetaraan dan tidak arogan atau non defensif serta selalu berupaya mendorong sikap positif, akan dapat mendorong terjadinya keefektifan proses pembelajaran ${ }^{15}$. Oleh sebab itu pemimpin penddikan ketika mengaplikasikan gaya atau aktifitas kepemimpinannya sangat tergantung pada pola organisasi yang melingkupnya. Dan juga dalam melaksanakan aktifitasnya seorang pemimpin dipengaruhi oleh berbagai macam faktor.

Faktor-faktor yang mempengaruhi aktifitas seorang pemimpin tersebut sebagaimana di kutip oleh Nanang Fattah sebagai berikut:

a. Kepribadian (personality), pengalaman masa lalu dan harapan pemimpin, hal ini mencakup nilai-nilai, latar belakang dan pengalamnnya akan mempengaruhi pilihan gaya kepemimpinannya.

b. Harapan dan perilaku atasan

c. Karakteristik, harapan dan perilaku bawahan mempengaruhi terhadap gaya kepemimpinan.

d. Kebutuhan tugas, setiap tugas bawahan juga akan mempengaruhi gaya kepemimpinan

e. Iklim dan kebijakan organisasi mempengaruhi harapan dan perilaku bawahan

f. Harapan dan perilaku rekan

Berdasarkan faktor-faktor tersebut, maka jelaslah bahwa kesuksesan pemimpin dalam aktivitasnya dipengaruhi oleh faktor-faktor yang dapat menunjang berhasilnya suatu kepemimpinan. Jadi disamping berhasilnya kepemimpinan dipengaruhi oleh latar belakang yang dimilki pemimpin,

15 Ary Ginanjar Agustin, Rahasia Sukses Membangun kecerdasan emosi dan spritual ESQ Emotional Spritual Quotient The ESQ Way 165, 1 Ihsan 6 Rukun Iman dan 5 Rukun Islam, (Jakarta: Agra, 2005), 17. 
seperti motovasi diri dan kedewasaan juga tercapai jika keharmonisan yang baik antara atasan dan bawahan

\section{Emotional Spritual Quotien (ESQ)}

Ari Ginanjar Agustina mendefinisikan Emotional Spritual Quotient (ESQ) sebagai sebuah kecerdasan yang meliputi emosi dan spritual dengan konsep universal yang mampu menghantarkan pada predikat memuaskan bagi dirinya dan orang lain, serta dapat menghambat segala hal yang kontraproduktif terhadap kemajuan umat manusia ${ }^{16}$. Dengan demikian, landasan utama dalam ESQ adalah kecerdasan spritual yang dalam kerangka ini dimaknai sebagai kemampuan untuk memberi makna ibadah terhadap setiap perilaku dan kegiatan, melalui langkah-langkah dan pemikiran yang bersifat fitrah menuju manusia yang seutuhnya (hanif) dan memiliki model dan memiliki pola pemikiran tauhid serta berprinsip hanya kepada Allah ${ }^{17}$.

Kalau emotional Quotient adalah kemampuan untuk mengenali perasaan diri sendiri dan kemampuan mengelola emosi dengan baik pada diri sendiri dan dalam hubungan dengan orang lain ${ }^{18}$, maka Spritual Quotient adalah kecerdasan jiwa. Ia dapat membantu manusia menyembuhkan dan membangun dirinya secara utuh, karena spritual berada dibagian paling dalam yang berhubungan langsung dengan kearifan dan kesadaran yang dengannya manusia tidak hanya mengakui nilai-nilai yang ada tetapi manusia secara kreatif menemukan nilai-nilai yang baru ${ }^{19}$.

Ary Ginanjar Agustian melahirkan satu model pelatihan ESQ yang telah memiliki hak paten tersendiri. Yang mana ESQ model ini dapat digunakan ketika seseorang berada diujung tanduk. Ujung adalah pembatas antara keteraturan dan kekacauan antara mengetahui diri dan sama sekali kehilangan jati diri.

Dengan demikian berarti orang yang cerdas secara spritual adalah orang yang mampu mengaktualisasikan nilai-nilai ilahiyah sebagai manifestasi dari aktifitasnya dalam kehidupan sehari-hari dan berupaya mempertahankan keharmonisan dan keselarasan dalam kehidupannya, sebagai wujud dari pengalamannya terhadap tuntutan fitrahnya sebagai makhluk yang memiliki ketergantungan terhadap kekuatan yang beradan diluar jangkauan dirinya yaitu Sang Maha Pencipta. ${ }^{20}$

16 Ary Ginanjar Agustin, Rahasia Sukses Membangun kecerdasan emosi dan spritual ESQ Emotional Spritual Quotient The ESQ Way 165, 1 Ihsan 6 Rukun Iman dan 5 Rukun Islam, (Jakarta: Agra, 2005), 57.

17 Dr. H. Fatah Syukur NC, M.Ag., Managemen Pendidikan Berbasis Pada Madarasah, (Semarang: PT. Pustaka Rizki Putra, 2002), 29.

18 Muhammad Muhyidin, Manajemen ESQ Power, (Jogjakarta; Diva Press, 2007), 76.

19 Zamroni, MA. \& Umiarso, ESQ \& Model Kepemimpinan, (Semarang: raSAIL Media Group, 2011), 55.

20 Ary Ginanjar Agustin, Rahasia Sukses Membangun kecerdasan emosi dan spritual ESQ Emotional Spritual Quotient The ESQ Way 165, 1 Ihsan 6 Rukun Iman dan 5 Rukun Islam, (Jakarta: Agra, 2005), 45. 
Kecerdasan intelektual membuat seseorang pandai dan kecerdasan emosional menjadikannya bisa mengendalikan diri, maka kecerdasan spritual memungkinkan hidupnya penuh arti. Ini diyakini merupakan kecerdasan tertinggi21. Oleh sebab itu langkah yang harus dilakukan adalah mencoba mengkonvergensikan secara tepat antara kecerdasan intelektual (IQ), kecerdasan emosi (EQ) dan kecerdasan spritual (SQ) dengan didasarkan pada nilai-nilai yang normatif. Menurut Ary Ginanjar meskipun pada akhirnya EQ dan SQ memiliki muatan yang berbeda namun sama-sama penting untuk dapat bersinergi antara satu dengan yang lain. Sebuah penggabungan gagasan kedua energi tersebut menyusun metode yang lebih dapat diandalkan dalam menemukan yang benar dan hakiki. Yang secara Ary Ginanjar menggambarkan konvergensi bentuk kecerdasan tersebut sebagai berikut ${ }^{22}$;

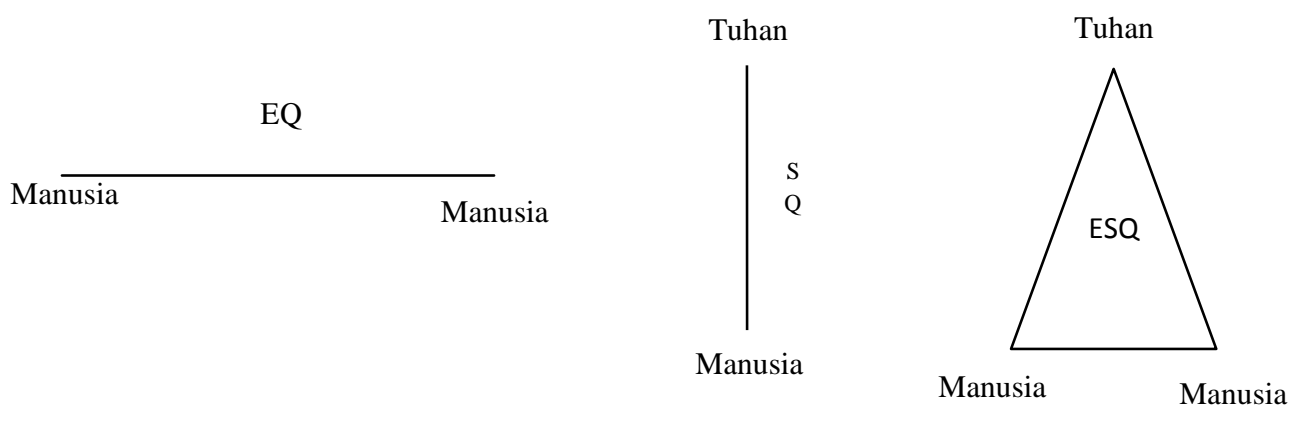

Gambar 1: Konvergensi dua kecerdasan

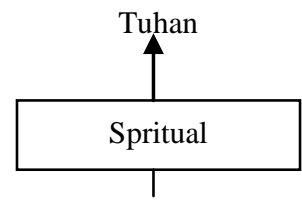

SQ (God Spot)

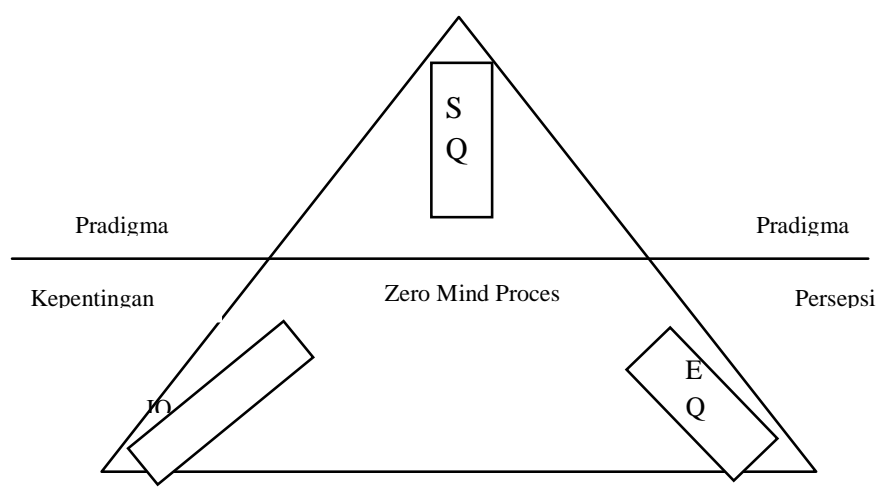

${ }^{21}$ Ary Ginanjar Agustin, Rahasia Sukses Membangun kecerdasan emosi dan spritual ESQ Emotional Spritual Quotient The ESQ Way 165, 1 Ihsan 6 Rukun Iman dan 5 Rukun Islam, (Jakarta: Agra, 2005), 45.

22 Zamroni, MA. \& Umiarso, ESQ \& Model Kepemimpinan, (Semarang: raSAIL Media Group, 2011), 59. 


\section{Gambar 2. Hubungan ketiga kecerdasan}

Pada tataran tersebut, sangat urgen untuk membahas diskursus mengenai kepemimpinan dengan pradigma Emotional Spritual Quotien (ESQ) dalam pemberdayaan manusia khususnya dalam mengkonstruk manusia yang manusiawi (humanity) di era modernis dengan berbagai problematika yang menjadi ciri khas fenomenanya. Menurut Zamroni dan Umiarso kepemimpinan yang efektif dalam mengatur proses kepemimpinan pendidikan yang efektif dalam harus mampu memproduk peserta didik dengan Intellegence Quotien (IQ) yang tinggi, sehingga bisa berkompetisi dalam menghadapi tantangan era modernis, sekaligus dapat menghantarkan peserta didik menjadi manusia yang sempurna (insan kamil) dengan kemampuan mengintegrasikan Emotional Quotien (EQ) dan Spritual Quotien (SQ) yang dapat memberikan konstribusi-konstribusikonstruktif pada sisi kemanusiaan manusia dan juga mampu mengentas problematika pendidikan di masa yang akan datang ${ }^{23}$. Qodri Azizy juga menegaskan bahwa kepekaan sosial, mencintai sesama, membantu yang kekurangan, empati dan simpati kepada orang lain adalah beberapa nilai yang harus ditanamkan kepada peserta didik ${ }^{24}$.

Dalam hal ini Emotional Spritual Quotien (ESQ) yang memiliki urgensitas sebagai problem solving dari kepemimppinan pendidikan atau bahkan pada persoalan pendidikan. Yang sudah diakaji diatas, maka ada beberapa poin penting yang seharusnya diperhatikan oleh pendidik selaku stake holder dalam dunia pendidikan. Karena kecenderungan klasik sepanjang sejarah manusia, bahwa konflik intelektual besar, acapkali terjadi karena adanya pemisahan, sebutlah misalnya, iman yang terpisah dengan rasio serta Emotional Quotien (EQ) yang bercerai dengan Intellegence Quotien (IQ). Pembelajaran di sekolah seakanakan atau bahkan memang tidak menyentuh pada tataran lingkungan praksis sebagai aplikasi dari Emotional Quotien (EQ) dan Spritual Quotien (SQ). Keadaan pembelajaran disekolah ini cenderung sangat teoritik dan tidak terkait dengan lingkungan di mana anak berada. Akibatnya peserta didik tidak mampu menerapkan apa yang dipelajari di sekolah guna memecahkan masalah kehidupan yang dihadapi dalam kehidupan sehari-hari. Pendidikan seakan mencabut peserta didik dari lingkungannya sehingga menjadi asing di masyarakatnya sendiri25. Menurut Ari Ginanjar Agustian, bahwa manusia yang

23 Zamroni, MA. \& Umiarso, ESQ \& Model Kepemimpinan, (Semarang: raSAIL Media Group, 2011), 59.

24 A. Qodri Azizy, Pendidikan (agama) Untuk Membanggun Etika Sosial (Mendidik Anak Sukses Masa Depan: Pandai dan Bermanfaat), (Semarang: Aneka Ilmu, 2003), 58.

25 Zamroni, MA. \& Umiarso, ESQ \& Model Kepemimpinan, (Semarang: raSAIL Media Group, 2011), 59. 
mempunyai spritualitas sejati tidak akan ditemukan di tempat-tempat ibadah, melainkan di korporasi-korporasi yang sukses ${ }^{26}$.

Upaya integralisasi ketiga kecerdasan tersebut mampu dirancang dan digambarkan secara holistik-integralistik serta dimunculkan dengan konsep doktrin Islam yang disebut dengan the ESQ ways 165 yaitu 1 (ihsan) 6 (iman) 5 (islam) dengan beberapa poin ${ }^{27}$ :

Zero Mind Process; yakni suatu usaha untuk menjernihkan kembali pemikiran menuju God Spot (fitrah), kembali kepada hati dan fikiran yang bersifat merdeka dan bebas dari belenggu; Mental Building; yaitu usaha untuk menciptakan format berfikir dan emosi berdasarkan kesadaran diri (selfawareness), serta sesuai dengan hati nurani dengan merujuk pada Rukun Iman; Mission Statement, Character Building, dan Self Controlling; yaitu usaha untuk menghasilkan ketangguhan pribadi (personal strength) dengan merujuk pada Rukun Islam; Strategic Collaboration; usaha untuk melakukan aliansi atau sinergi dengan orang lain atau dengan lingkungan sosialnya untuk mewujudkan tanggung jawab sosial individu; dan Total Action; yaitu suatu usaha untuk membangun ketangguhan sosial

26 Ary Ginanjar Agustin, Rahasia Sukses Membangun kecerdasan emosi dan spritual ESQ Emotional Spritual Quotient The ESQ Way 165, 1 Ihsan 6 Rukun Iman dan 5 Rukun Islam, (Jakarta: Agra, 2005), 36.

27 Ary Ginanjar Agustin, Rahasia Sukses Membangun kecerdasan emosi dan spritual ESQ Emotional Spritual Quotient The ESQ Way 165, 1 Ihsan 6 Rukun Iman dan 5 Rukun Islam, (Jakarta: Agra, 2005), 17. 


\section{Peta Hubungan Kerja antara IQ, EQ dan SQ}

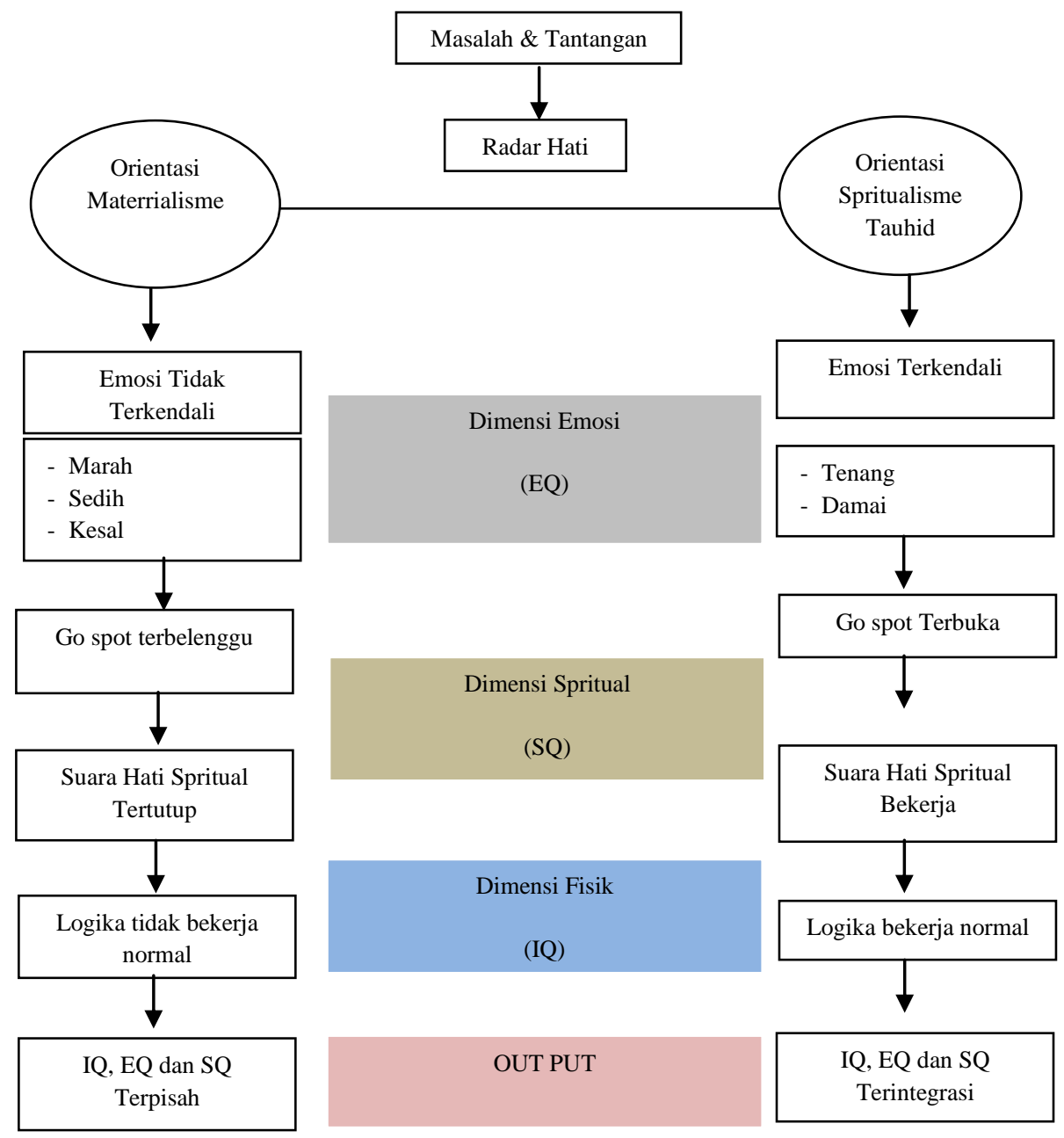

\section{ESQ dalam Kepemimpinan Pendidikan}

Dalam hal ini penulis ingin fokuskan pada empat fungsi kepemimpinan dalam pendidikan yang di integralisasikan dengan konsep Emotional Spritual Quotien (ESQ) model Ary Ginanjar. Yaitu fungsi perencanaan (planing), fungsi pengorganisasian (organizing), fungsi pelaksanaan (actuating), dan fungsi pengawasan (controling)

\section{ESQ dalam Fungsi Perencanaan}

Perencanaan menjadi pegangan setiap pimpinan da pelaksanaan untuk dilaksanakan. Dengan demikian, melalui perencanaan dapat dipersatukan kesamaan pandangan, sikap dalam pelaksanaan di lapangan. Dapat pula dikatakan bahwa pimpinan harus mengetahui secara pasti tujuan jangka panjang, untuk kemudian rencana janka panjang menengah dan diatas perencanaan jangka panjang menengah ini pula, ia harus menentukan perencanaan jangka jangka pendek. Perencanaan jangka pendek ini harus di rinci berdasarkan skala prioritas, 
mana yang harus dikerjakan terlebih dahulu dan secara bertahap serta terencana melaksanakan tahap-tahap berikutnya sampai tujuan jangka pendek itu dapat tercapai sepenuhnya, perlu diadakan evaluasi untuk menyempurnakan langkah selanjutnya ${ }^{28}$.

Pada tataran ini, kepala sekolah mampu membangun kesatuan visi dan misi pada pluralitas misi dan visi dari komponen sekolah pada satu persepsi dalam menjalankan program sekolah. Sebab visi dan misi merupakan tonggak utama yang dengan kemampuan untuk menyebutkan secara berulang-ulang melalui ucapan, pikiran dan hati sekaligus, visi dan misi sekolah akan mampu mendorong pikiran untuk menjadi spirit dan motivasi yang kuat, sehingga membekas dihati.

Ucapan yang keras dari visi dan misi, diterapkan oleh kepalah sekolah untuk membangun kekuatan pikiran bawah sadar, sehingga akan mendarah daging di dalam diri komponennsekolah menjadi sesuatu kekuatan, itulah yang dalam ESQ model disebut sebagai Repetitive magic power. ${ }^{29}$

Kekuatan pikiran bawah sadar ini yang akhirnya difungsikan dalam merencanakan dan menjalankan program kegiatan sekolah. Kekuatan tersebut membentuk spirit untuk terus melakukan proses perencanaan, sebab perencanaan dalm konteks sekolah ini merupakan suatu proses yang tidak berakhir bila rencana tersebut telah ditetapkan, rencana ynag harus dimplementasikan. Kepala sekolah sering mengimbau bahwa setiap saat selama proses implementasi dan pengawasan, rencana-rencana mungkin memerlukan modifikasi agar tetap berguna. Oleh sebab itu, perencanaan harus mempertimbangkan kebutuhan fleksibilitas, agar mampu menyesuaikan diri dengan situasi dan kondisi baru secepat mungkin. Jadi Menurut Zamroni dan Umiarso perencanaan adalah proses dimana manajemen memutuskan tujuan dan cara mencapainya. Perbedaan pelaksanaan adalah tipe dan tingkat perencanaan yang berbeda pula. Perencanaan dalam organisasi pendidikan adalah esensial, karena dalam kenyataannya perencanaan memegang peranan lebih dibanding fungsi-fungsi manajemen

28 Zamroni, MA. \& Umiarso, ESQ \& Model Kepemimpinan, (Semarang: raSAIL Media Group, 2011), 195.

29 Repetitive Magic Power (RMP)Yaitu, suatu metode pengulang-ulangan kalimat agar nilai-nilai yang dibacakan masuk dalam pikiran bawah sadar mereka dan pada akhirnya membentuk karakter yang diinginkan. Islam sebagai agama yang mengandung nilainilai Ihsan (1), enam rukun Iman (6) dan lima rukun Islam (5) ternyata juga memiliki mekanisme tersebut, bahkan jauh lebih dahsyat. Saat salat lima waktu misalnya, kita diharuskan membaca Al Fatihah. Berarti, dalam sehari seorang Muslim akan membaca Al Fatihah 17 kali. Dalam sebulan 510 kali (17x30) dan 6.205 kali dalam setahun (17x365). Jika ia salat selama 10 tahun saja, maka Al Fatihah dibacanya 62.050 kali! Dan akan terus bertambah, karena salat lima waktu dilakukan seumur hidup. Ini merupakan satu metode yang dahsyat, karena Al Fatihah adalah intisari Alquran yang tujuh ayatnya mengandung nilai-nilai luhur. Lihat di http://ludvy4life.blogspot.com/2008/04/repetitive-magic-power-rmp.html 
lainnya. Fungsi-fungsi pengorganisasian, pengarahan dan pengawasan hanyalah melaksanakan keputusan-keputusan perencanaan ${ }^{30}$.

Ada beberapa tahapan dalam perencanaan yang dilkaukan oleh kepala sekolah, yaitu: (1) Menetapkan tujuan atau serangkaian tujuan, (2) Merumuskan keadaan saat ini, (3) Mengidentifikasikan segala peluang dan hambatan, (4) Mengembangkan rencana atau serangkaian kegiatan dalam pencapaian tujuan.

Dalam tahapan tersebut, kepala sekolah melibatkan seluruh komponen sekolah seperti dewan guru, komite sekolah dan wali murid dengan sikap demokratis. Dengan sikap kepemimpinan yang dilakukan oleh kepala sekolah ini, pada tataran perencaan program-program sekolah mampu menyentuh dan mengimplementasikan spritualitas dalam kehidupan sekolah dan juga mampu menampung aspirasi masyarakat sekitar sebagai bentuk merasakan perasaan orang lain. Bahkan kegiatan ini juga menambah kepercayaan masyarakat bahwa sekolah benar-benar berusaha untuk mengantarkan peserta didik menuju masa depan mereka secara akademik, mental dan spritual. Dan secara tidak langsung kepala sekolah memberikan pembelajaran kontekstual pada civitas akademika tentang sikap untuk bertoleransi antar sesama, ikhlas dalam menjalankan aktivitas dan merasakan kehadiran ilahi ${ }^{31}$.

ESQ dalam Fungsi Pengorganisasian

Pengorganisasian merupakan proses penyusunan struktur organisasi yang sesuai dengan tujuan organisasi, sumber daya yang dimilikinya, dan lingkungan yang melingkupinya. Dua aspek utama proses susunan struktur organisasi yaitu departementalisasi dan pembagian kerja. Departementalisasi adalah pengelompokan kegiatan-kegiatan kerja organisasi agar kegiatan-kegiatan sejenis saling berhubungan dapat dikerjakan bersama. Hal ini akan tercermin pada struktur formal suatu organisasi dan tmpak atau ditunjukkan oleh bagan suatu organisasi. Pembagian kerja adalah perincian tugas pekerjaan agar setiap individu pada organisasi bertanggung jawab dalam melaksanakan sekumpulan kegiatan. Kedua aspek ini merupakan dasar proses pengorganisasian suatu organisasi untuk mencapai tujuan yang telah ditetapkan ${ }^{32}$.

Dalam upaya mengintegarlisasikan dengan ESQ maka kepala sekolah sebagai pemimpin pendidikan tidak serta merta menjalankan dan mengorganisasikan semua program-programnya. Akan tetapi banyak melakukan penggalian informasi guna mendukung, mengkolaborasikan antara program satu dengan program yang lainnya. Kepala sekolah harus banyak banyak berkoordinasi dengan para tokoh, ulama dan para trainer ESQ misalnya sebagai bahan

30 Zamroni, MA. \& Umiarso, ESQ \& Model Kepemimpinan, (Semarang: raSAIL Media Group, 2011), 196.

31 Zamroni, MA. \& Umiarso, ESQ \& Model Kepemimpinan, (Semarang: raSAIL Media Group, 2011), 196.

32 Zamroni, MA. \& Umiarso, ESQ \& Model Kepemimpinan, (Semarang: raSAIL Media Group, 2011), 198. 
pertimbangan, sehingga program ESQ yang disisipkan pada program sekolah menjadi bagian yang mengintegral dalam diri komponen sekolah.

Kepala sekolah juga dalam mengatur komponen sekolah pada job description masing-masing sesuai dengan skill dan kemampuan dengan tumpuan stadium ikhlas dalam menjalankan setiap program yang menjadi tanggung jawab masingmasing komponen sekolah tersebut. Dengan demikian, pada aspek ini kepala sekolah telah melakukan perombakan kesadaran masyarakat sekolah menuju kesadaran diri komponen sekolah pada konsep ihsan. Ihsan menghendaki bahwa manusia harus menyadai akan kehadiran Allah dan berprilaku dengan sebaikbaiknya, bahkan ihsan juga menuntut untuk berpikir, merasa, dan berniat secara baik dalam menjalankan program sekolah

\section{ESQ dalam Fungsi Pelaksanaan}

Pelakasanaan merupakan hubungan manusia dalam kepemimpinan yang mengikat para bawahan agar bersedia mengerti dan menyumbangkan tenaganya secara efektif serta efisien dalam pencapaian tujuan suatu organisasi. Di dalam manajemen pelaksanaan ini bersifat kompleks karena disamping menyangkut manusia juga menyangkut berbagai tingkah laku dari manusia-manusia itu sendiri. Manusia dengan berbagai tingkah lakunya yang berbeda-beda. Menurut Zamroni dan Umiarso ada beberapa prinsip yang dilakukan oleh pimpinan dalam melakukan pengarahan, yaitu; Prinsip mengarah kepada tujuan, Prinsip keharmonisan dengan tujuan, dan Prinsip kesatuan komando ${ }^{33}$.

Kepala sekolah menyerahkan sepenuhnya kepada bawahan untuk melaksanakan program sesuai dengan perencanaan dan diaharapkan tidak menyimpang dari prinsip-prinsip kepemimpinan. Kepala sekolah mendorong komponen sekolah untuk bergerak, melakukan yang terbaik sesuai dengan tuntutan yang telah digariskannya. Pada tataran ini, suara hati yang dijalankan oleh kepala sekolah menggunakan kerangka suara hati yang berasala dari komponen sekolah yang berlandaskan pada spritualitas. Dengan demikian masalah-masalah yang muncul didalam organisasi sekolah ataupun dalam kehidupan komponen sekolah dapat disikapi secara arif dengan pemanfaatan kecerdasan emosianal spritual.

\section{ESQ dalam Fungsi Pengawasan}

Controlling sering juga disebut pengendalian adalah satu fungsi manajemen yang berupa mengadakan penilaian, bial perlu mengadakan koreksi sehingga apa yang dilakukan bawahan dapat diarahkan ke jalan yang benar dengan maksud tujuan yang telah digariskan semula. Pengawasan adalah proses pengamatan dari pada pelaksanaan seluruh kegiatan organisasi untuk menjamin agar semua pekerjaan yang sedang dikerjakan berjalan sesuai rencana yang ditetapkan ${ }^{34}$.

33 Zamroni, MA. \& Umiarso, ESQ \& Model Kepemimpinan, (Semarang: raSAIL Media Group, 2011), 200.

34 Zamroni, MA. \& Umiarso, ESQ \& Model Kepemimpinan, (Semarang: raSAIL Media Group, 2011), 203. 
Kepemimpinan kepala sekolah harus mampu menerapkan kecerdasan emotional dan spritual dalam memenej organisasi sekolah. Kecerdasan spritual yang diterapkan adalah kecerdasan untuk menghadapi persoalan makna atau value, yaitu kecerdasan untuk menempatkan perilaku dan hidup pemimpin dalam hal ini kepala sekolah dalam konteks makna yang lebih luas dan kaya terutama yang menyangkut aspek kependidikan, dan juga mampu memberikan evaluasi untuk menilai bahwa tindakan atau jalan hidup sesorang lebih bermakna dibandingkan dengan yang lain.

\section{Penutup}

Kepemimpinan pendidikan adalah kemampuan untuk menggerakkan pelaksanaan pendidikan untuk mencapai tujuan pendidikan, tujuan pendidikan disini sebagaimana diketahui bahwa tujuan humanaity atau lebih dikenal memanusiakan manusia. Ada banyak karakteristik ataupun tipe dari seorang pemimpin, namun yang menjadi target serta idealitas seorang pemimpin adalah pemimpin yang demokratis yang mana Yang mana dalam kepemimpinan ini seorang pemimpin selalu mengikut sertakan seluruh anggota kelompoknya dalam mengambil keputusan, kepala sekolah yang bersifat demikian akan selalu menghargai pendapat atau kreasi anggotanya/guru-guru yang ada dibawahnya dalam rangka membina sekolahnya. Kepala sekolah memberikan sebagian kepemimpinannya/kekuasaannya kepada bawahan, sehingga para bawahan merasa turut bertanggung jawab terhadap pelaksanaan program pendidikan dan pengajaran di sekolah. Dan penerapan ESQ sangat cocok diintegralisasikan dengan tipe ini. Dalam penerapan ESQ pada kepemimpinan pendidikan juga dapat disimpulkan sebagai berikut;

1. ESQ dalam fungsi perencanaan, menyusun program dengan melibatkan dewan guru, komite sekolah dan wakil murid

2. ESQ dalam fungsi Pengorganisasian, melakukan penggalian informasi guna mendukung, mengkolaborasikan antara program satu dengan program yang lainnya.

3. ESQ dalam fungsi Pelaksanaan, melakukan kegiatan-kegiatan positif seperti shalat dhuha bersama dll.

4. ESQ dalam fungsi Pengawasan, penetapan standar pelaksanaan, analisa penyimpangan dan pengambilan tindakan koreksi. 


\section{DAFTAR PUSTAKA}

Agustian, Ary Ginanjar, 2005, Rahasia Sukses Membangun kecerdasan emosi dan spritual ESQ Emotional Spritual Quotient The ESQ Way 165, 1 Ihsan 6 Rukun Iman dan 5 Rukun Islam, Jakarta: Agra.

Jakarta: Arga.

2004, Rahasis Sukses membengkitkan ESQ Power, cet. V,

Annaurrahman, 2009, Belajar dan pembelajaran, Bandung: Alfabeta.

Azizy, A. Qodri, 2003, Pendidikan (agama) untuk membanggun etika sosial (Mendidik Anak Sukses Masa Depan: Pandai dan Bermanfaat), Semarang: Aneka Ilmu.

Danim, Sudarwan dan Suparno, 2009, Managemen dan Kepemimpinan Transformasional Kekepala Sekolahan, Jakarta: Renika Cipta.

Hendayat Soetopo, Drs., Drs. Waty Soemanto, 1984, Kepemimpinan dan Supervisi Pendidikan, Malang: PT. Bina Aksara.

Langgulung, Hasan, 2005, Pendidikan Dalam Perspektif Al-Qur'an, (Yogyakarta: Mikraj.

Muhyidin, Muhammad, 2007, Manajemen ESQ Power, cet. III, Jogjakarta: Diva Press.

Syarif, Zainuddin, Dr. M.Ag., 2007, Dinamisasi Manajemen Pesantren ; dari tradisional hingga modern, Yogyakarta: Sunan Kalijaga Press.

Syukur, Fatah Dr. H. NC, M.Ag., 2002, Managemen Pendidikan Berbasis Pada Madarasah, Semarang: PT. Pustaka Rizki Putra.

Wahyosumidjo, 2010, Kepemimpinan Kepala Sekolah, Jakarta; PT RajaGrafido Persada.

Zamroni, MA. \& Umiarso, 2011, ESQ \& Model Kepemimpinan Pendidikan, Semarang: raSAIL Media Group.

http://ludvy4life.blogspot.com/2008/04/repetitive-magic-power-rmp.html. diambil pada tanggal 14 April 2013 